UC 577,$1 ; 61$

ISSN 0354-3447

Jugoslov Med Biohem 23: 161-164, 2004

Originalni naučni rad

Original paper

\title{
BIOCHEMICAL AND MOLECULAR BIOLOGICAL ASPECTS OF GLUCOSE INTOLERANCE IN ELDERLY PERSONS
}

\author{
Snežana Đurica ${ }^{1}$, Goran Korićanac ${ }^{2}$, Nevena Ribarac-Stepić ${ }^{2}$, Mladen Davidović ${ }^{1}$, \\ Dragoslav Milošević ${ }^{1}$, Miroljub Petrović ${ }^{3}$, Miodrag Rajić ${ }^{3}$ \\ ${ }^{1}$ University School of Medicine, Zvezdara Department of Internal Diseases, \\ University Clinical Centre, Belgrade \\ 2Vinča Institute of Nuclear Sciences, Laboratory of Molecular Biology, Belgrade \\ 3 University School of Pharmacy, Belgrade, Serbia and Montenegro
}

\begin{abstract}
Summary: Changes in carbohydrate metabolism in elderly persons have drawn considerable attention but the findings from different studies are in contrast and are even controversial. The insulin receptors in erythrocytes were studied in elderly euglycaemic patients and in a middle-aged control group. The examined persons were also subjected to measurements of blood glucose, insulin and C-peptide concentrations, before and 3 hours after a dietetic meal. In the present study it was found that in spite of the maintained insulin level and C-peptide secretion, some structural and corresponding changes in membrane insulin receptors and the binding site caused differences in postreceptor responses in elderly persons. The examined groups, consisted of 29 males, average age of 66 years (65-70), with normal serum glucose level and 19 middle-aged males, average age of 42 years (32-48), with normal glycoregulation. In basal condition, elderly persons have both normal morning serum insulin $(19.68 \pm 4.00 \mathrm{mU} / \mathrm{L})$ and C-peptide $(2.04 \pm 0.78 \mathrm{nmol} / \mathrm{L})$ level. In elderly persons, the number of high affinity insulin receptors in erythrocytes membrane is $22.80 \pm 6.18$ but the formed insulin-high affinity receptors were not stable. Dissociation constant $(\mathrm{Kd} 1)$ indicates its elevated dissociation $(0.11 \pm 0.04)$. At the same time the number of insulin low affinity binding sites is increased (13 $273 \pm 5572)$ with a fast dissociation of the hormone (13.99 \pm 3.37$)$. Food intake raised the number of high affinity receptors compared to the basal value. Alteration in insulin binding affinity suggests the structural and corresponding changes in membrane receptors that may cause differences in postreceptors responses in elderly persons.
\end{abstract}

Key words: glucose intolerance, insulin, receptors, binding sites, elderly people

\section{Introduction}

Normal serum glucose value is a remarkable component in maintenance of homeostasis. Glucose is an essential substrate in vital organs metabolism such as the brain, the heart, the muscles, the liver, and the others. In certain circumstances, including the ageing, numerous very complex changes occur in carbohydrates, lipids and proteins metabolism. Insulin promotes glucose uptake in various tissues (1). All insulin biological effects are mediated by its previous binding to the specific tissue receptors. Thus, the changes in the characteristics of these receptors, as

Address of correspondence

Prof dr Snežana Đurica

University School of Medicine, Zvezdara Department

of Internal Diseases, University Clinical Centre

11000 Belgrade, D. Tucović 161

e-mail: djurica@EUnet.yu well as the changes in post receptors events may influence the metabolic processes (2). The age related changes in insulin binding to the specific receptors in various tissues occur (3), but the mechanisms of very complex peripheral insulin resistance pathophysiology and glucose intolerance in elderly persons are not well explained.

The aim of this study was to examine the quality of glucoregulation, erythrocytes insulin receptors, and insulin binding characteristics, plasma insulin level and the $\mathrm{C}$-peptide serum concentration in elderly persons.

\section{Patients and Methods}

Subjects. We studied a group of 29 euglycaemic male persons, average age of 66 years (65-70). All analyzed parameters were compared with those obtained in a control group, of 19 middle-aged males, 
average age of 42 years (32-48) with normal glycoregulation.

Methods. The morning glucose values, plasma insulin and C-peptide serum levels were analyzed in blood samples obtained by venepunction before the breakfast (basal value) and three hours (3h) later i.e. after a dietetic meal, using the standardized biochemical test for glucose and radioimmunoassay (produced by INEP-Diagnostics, Yu) for determination of serum insulin and C-peptide serum concentrations. The values, assumed to be normal, were accepted in accordance with the methods used. The quality control was performed in all cases.

Insulin binding assay was performed in accordance with our own modification (4). Scatchard plots analysis data were used to determine the binding capacities and dissociation constants (5). The curvilinear Scatchard plots were resolved into two components; high affinity low capacity $\left(\mathrm{N}_{1}\right)$ and low affinity high capacity $\left(\mathrm{N}_{2}\right)$ component. The dissociation constants $\left(\mathrm{Kd}_{1}\right.$ and $\left.\mathrm{Kd}_{2}\right)$ were also calculated (6). Binding capacities $(\mathrm{mol} / \mathrm{L})$ were converted to the receptors number per erythrocytes.

Oral glucose tolerance test (oGTT) was proved at the same manner in all analyzed persons, using $75.0 \mathrm{~g}$ of pure glucose.

Statistical analysis. The obtained data were evaluated by parametric statistics (7). The results were expressed by the mean value, resulting from two tests of the same sample with corresponding standard error $(\bar{x} \pm S E)$. The significance of observed differences was tested by one-way analysis of variance $\left(\mathrm{F}_{\mathrm{emp}}\right)$ in the same group (8) and by Student's t-test between the analyzed groups.

\section{Results}

The patients included in this study were not obese. Their body mass indexes (BMI) were normal, obtained by Mini nutrition assessment (9): $22 \mathrm{~kg} / \mathrm{m}^{2} \pm$ $2.80(\bar{x} \pm \mathrm{SD})$. Elderly persons (»physiological ageing «), i.e. group the examined, have normal morning blood glucose values (Table I).

Table I Serum glucose, insulin and C-peptide morning levels in elderly and middle-aged persons

\begin{tabular}{|l|c|c|}
\hline $\begin{array}{l}\text { Parameters } \\
\text { (reference values in brackets) }\end{array}$ & Elderly persons & $\begin{array}{c}\text { Middle-aged } \\
\text { control group }\end{array}$ \\
\hline Glucose $(3.8-6.1 \mathrm{mmol} / \mathrm{L})$ & $5.64 \pm 0.30$ & $4.56 \pm 0.27$ \\
\hline Insulin $(5-30 \mathrm{~mL} / \mathrm{L})$ & $15.04 \pm 1.87 *$ & $19.68 \pm 4.00 *$ \\
\hline C-peptide $(2.1-4.0 \mathrm{nmol} / \mathrm{L})$ & $1.34 \pm 0.43^{*}$ & $2.04 \pm 0.78^{*}$ \\
& $* \mathrm{p}<0.05$ & ${ }^{*} \mathrm{p}<0.05$ \\
\hline
\end{tabular}

The significant difference $(p<0.05)$ in serum insulin and C-peptide levels between analyzed groups was proved. However, the curves, indicating the quality of glucoregulation, differed significantly (Figure 1).

In an attempt to elucidate the site of observed glucose intolerance during ageing, the binding of 125Iinsulin to isolated humans erythrocytes was analyzed in all persons included in the study. Scatchard analysis indicated that a decrease in receptors number (Table II), rather than receptors affinity seems to be the cause of the lowered specific insulin binding in elderly. This assumption is supported by the evidence indicating that the stability of formed insulin-receptor complex is higher $(p<0.10)$ in the control group. However, the dissociation constant is not statistically significant between compared groups (Table II).

The results obtained by analysis of the low affinity binding sites demonstrate the heterogeneity. A higher number $(\mathrm{p}<0.01)$ of low affinity binding sites (13 $273 \pm 5$ 572, $\bar{x} \pm$ SE) was observed in elderly. Insulin dissociates rapidly $(p<0.025)$ from the complex, which were formed with low affinity binding sites $(13.99 \pm 3.37, \bar{x} \pm S E)$.

After a dietetic meal serum insulin level was higher $(p(F)<0.01)$ in the group of elderly persons $(46.56$ \pm 14.27 versus $15.04 \pm 1.87, \overline{\mathrm{x}} \pm \mathrm{SE}$ before). Very similar finding for $\mathrm{C}$-peptide serum concentration $3 \mathrm{~h}$ after the meal was obtained $(3.39 \pm 0.86)$ when compared to the basal C-peptide $(1.34 \pm 0.43)$ level ( $p$ $(\mathrm{F})<0.10)$.

However, in middle-aged group of persons both, serum insulin and C-peptide levels reached $55.24 \pm$ 4.20 and $4.18 \pm 0.52$, respectively.

In order to elucidate the site of the observed insulin resistance occurring in the elderly, insulin erythrocytes receptors were analyzed 3 hours after the meal. The number of the high affinity receptors decreased $(p(F)<0.05)$ after the meal in euglycaemic elderly people $(14.20 \pm 2.80)$ in comparison with the

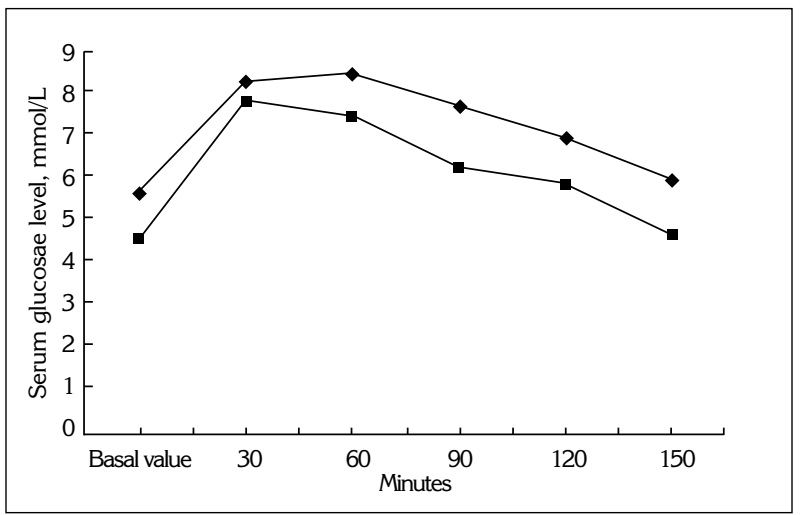

Figure 1. Glucose tolerance test $(75 \mathrm{~g})$ in elderly $(-\mathbf{-})$ and middle-aged $(-)$ ) persons 
Table II Erythrocytes insulin receptors characteristics in elderly and middle-aged people

\begin{tabular}{|c|c|c|c|c|c|}
\hline Groups & Specific binding of ${ }^{125}$ I insulin/erythrocyte & Receptors & Number & Dissociation & constant \\
\hline & & $\begin{array}{l}\text { High affinity } \\
\left(\mathrm{N}_{1}\right)\end{array}$ & $\begin{array}{l}\text { Low affinity } \\
\left(\mathrm{N}_{2}\right)\end{array}$ & $\left(\mathrm{Kd}_{1}\right)$ & $\left(\mathrm{Kd}_{2}\right)$ \\
\hline Elderly & $2.66 \pm 0.46$ & $14.65 \pm 1.70$ & $13273 \pm 5572$ & $0.11 \pm 0.04$ & $13.99 \pm 3.37$ \\
\hline Middle-aged & $3.55 \pm 0.66$ & $22.80 \pm 6.18$ & $5069 \pm 1532$ & $0.09 \pm 0.02$ & $5.25 \pm 1.31$ \\
\hline $\mathrm{p}$ & $\mathrm{p}<0.1$ & $\mathrm{p}<0.05$ & $\mathrm{p}<0.01$ & $\mathrm{p}<0.10$ & $\mathrm{p}<0.025$ \\
\hline
\end{tabular}

Table III Erythrocytes insulin receptors characteristics in analyzed groups $3 \mathrm{~h}$ after the meal

\begin{tabular}{|l|c|c|c|c|c|}
\hline Groups & Specific binding of 125I insulin/erythrocyte & Receptors & Number & \multicolumn{2}{|c|}{ Dissociation } \\
\hline & & $\begin{array}{c}\text { High affinity } \\
\left(\mathrm{N}_{1}\right)\end{array}$ & $\begin{array}{c}\text { Low affinity } \\
\left(\mathrm{N}_{2}\right)\end{array}$ & $\begin{array}{c}\left(\mathrm{Kd}_{1}\right) \\
\left(\mathrm{Kd}_{2}\right)\end{array}$ \\
\hline Elderly & $1.93 \pm 0.18$ & $14.20 \pm 2.80$ & $8074 \pm 3087$ & $0.38 \pm 0.28$ & $10.41 \pm 4.08$ \\
\hline Middle-aged & $3.18 \pm 0.46$ & $26.82 \pm 5.19$ & $9108 \pm 2425$ & $0.11 \pm 0.02$ & $14.24 \pm 3.30$ \\
\hline $\mathrm{P}$ & $\mathrm{p}<0.01$ & $\mathrm{p}<0.05$ & $\mathrm{p}<0.10$ & $\mathrm{p}<0.05$ & $\mathrm{p}<0.10$ \\
\hline
\end{tabular}

same parameter before the meal $(14.65 \pm 1.70)$. The dissociation constant $(0.38 \pm 0.28)$ was significantly $(\mathrm{p}<0.05)$ higher if compared to that before the meal and the control $(0.11 \pm 0.02)$ group (Table III). Decreased insulin low affinity binding sites were found after the meal in elderly persons (8 $074 \pm 3087 ; \bar{x} \pm$ $\mathrm{SE}$ ) in physiological ageing process. This finding is statistically significantly lower $(\mathrm{p}(\mathrm{F})<0.05)$ in comparison with the same parameter in the elderly before the meal (13 $273 \pm 5$ 572) as well as compared to that observed in middle-aged control group (9 $108 \pm$ $2425)$. Thus, it seems that the low affinity binding sites are "spare» binding sites, but without a stability of forming an insulin-binding site complex. The consequence is probably the postreceptor transmission dysfunction which can be the basis of the resistance to insulin action in elderly persons.

\section{Discussion}

Although it is accepted that glucose intolerance is a common feature in advanced years, the effect of ageing on carbohydrate metabolism has not been completely clarified. Ageing is often accompanied by hyperglycaemia in non-diabetics (10) and may induce further deterioration of glucose homeostasis. The possible explanation for this, in a mild degree disturbed carbohydrate metabolism in elderly persons, could be some modification of insulin action at the target tissue level, including the receptor and post-receptor events, by changing the endocrine status, which occurred in ageing processes (11). However, the mechanisms by which some hormones modulate these processes are not yet understood, and the mechanism of insulin resistance as the consequence of ageing is still unknown. Thus, the goal of this study is to examine the possibility if the glucoregulation in elderly persons is due to either the modification of receptors number and affinity or to changes in endogenous insulin secretion, indicated by $\mathrm{C}$-peptide. All the above-mentioned data suggested the existence of some changes in insulin receptor characteristics. The number of high affinity receptors was not paralleled by an enhanced effect of hormone because the dissociation constant of high affinity receptors was higher in elderly persons than in middle-aged controls. Additionally, alteration in insulin binding affinity suggests some structural and corresponding changes in membranes receptors, that may cause some further differences in biological expected, post-receptor response, in elderly persons.

The data of this study support the hypothesis that ageing induced insulin resistance and mostly post-insulin binding defects, which could be at least partially located at the insulin receptor kinase, which is able to phosphorylate various proteins and other substrates (12), as well as at the level of synthesis and activity of enzymes involved in glucose metabolism, but not in the synthesis of insulin receptors.

This study provides the one more evidence on the hormone involvement in the ability of insulin receptor, which can regulate glucose level during the ageing. It seems, therefore, that ageing modulates the properties of insulin receptor complex and consequently the response to insulin action.

The obtained results suggest that the peripheral insulin resistance could be involved in very complex pathophysiology of glucose intolerance usually occurring in the elderly during normal ageing process.

Acknowledgement. This study was supported, in part, by the grant 1999, from Ministry of Sciences, Technology and Development Republic of Serbia. 


\title{
BIOHEMIJSKI I MOLEKULARNO BIOLOŠKI ASPEKTI INTOLERANCIJE GLUKOZE KOD STARIJIH OSOBA
}

\author{
Snežana Đurica ${ }^{1}$, Goran Korićanac 2 , Nevena Ribarac-Stepić ${ }^{1}$, Mladen Davidović ${ }^{1}$, \\ Dragoslav Milošević ${ }^{1}$, Miroljub Petrović ${ }^{3}$, Miodrag Rajić ${ }^{3}$ \\ ${ }_{1}^{1}$ Medicinski fakultet, Interna klinika "Zvezdara« Kliničkog univerzitetskog centra, Beograd \\ 2Institut nuklearnih nauka »Vinča«, Laboratorija za molekularnu biologiju, Beograd \\ 3Farmaceutski fakultet, Beograd
}

\begin{abstract}
Kratak sadržaj: Promene metabolizma ugljenih hidrata starijih osoba zaslužuju pažnju, uprkos različitim stavovima. Kod starijih normoglikemičnih osoba, analizirani su receptori za insulin na eritrocitima i nalaz je upoređen sa istim kod srednjedobnih osoba. Takođe je svim osobama, obuhvaćenih studijom, određena koncentracija glikemije našte, insulina seruma i C-peptida, pre jela i 3 časa posle obroka. Iako je lučenje insulina i C-peptida očuvano, kod starijih osoba postoje izvesne promene konformacije receptora i vezujućih mesta za insulin, što uzrokuje razlike u postreceptorskom odgovoru na ovaj hormon. Studijom je obuhvaćeno 29 normoglikemičnih osoba muškog pola prosečne starosti 66 godina (65-70) i 19 osoba prosečne starosti 42 godine (32-48) normalne glikoregulacije. U bazalnim uslovima starije osobe imaju normalne koncentracije insulina (19,68 \pm 4,00 $\mathrm{mU} / \mathrm{L}$ i C-peptida $(2,04 \pm 0,78 \mathrm{nmol} / \mathrm{L})$. Broj receptora visokog afiniteta na eritrocitima prema insulinu, kod starijih osoba je $22,80 \pm 6,188$, ali formirani kompleks nije stabilan, što potvrđuje niska konstanta disocijacije $\left(\mathrm{Kd}_{1}\right.$ : $0,11 \pm 0,04)$. Istovremeno, broj vezujućih mesta niskog afiniteta je povećan (13 $273 \pm 5572$ ), sa brzim disociranjem hormona iz kompleksa $(13,99 \pm 3,37)$. Unos hrane povećava broj visokoafinitetnih receptora u poređenju sa bazalnim vrednostima. Poremećaj afiniteta vezivanja insulina sugeriše strukturne i promene konformacije receptora što moze uzrokovati razlike u postreceptorskom odgovoru starijih osoba na delovanje insulina.
\end{abstract}

Ključne reči: intolerancija glikoze, insulin, receptori, vezujuća mesta, starije osobe

\section{References}

1. Czech MP. Molecular basis of insulin action. Ann Rev Biochem 1997; 46: 359-84.

2. Muller-Wieland D, Streicher R, Siemeister G. Krone W. Molecular biology of insulin resistence. Exp Clin Endocrinol 1993; 101: 17-29.

3. Devaskar SU, Grim PF, Devascar UP. A differential effect of thyroxine and glucocorticoids on fetal brain and heart insulin receptor. Pediatr Res 1985; 19: 192-98.

4. Ribarac-Stepić N, Kovačina K, Zamaklar M, Devečerski $M$. Detection of compounds in serum inhibiting insulin binding to erythrocytes receptors. Endocrinol Exp 1988; 22: $203-9$.

5. Scatchard G. The attraction of proteins for small molecules and ions. Ann NY Acad Sci 1947; 51: 660-72.

6. Thacur AK, Jaffe ML, Rodbard D. Graphical analysis of ligand binding systems: evaluation by Monte Carlo studies. Anal Biochem 1980; 107: 279-95.

7. Hill B. Principles of Medical Statistics. Lancet 1961.

8. Fisher Y. Statistical tables for biological, agrocultural and medical research, Oliver and Boyd, Edinburgh 1957.

9. Guigoz Y, Vellas B, Garry PJ. Nutrition in the Elderly, Serdi publishing Co. 1995, New York, Paris, Tokyo 15-61.

10. Olefsky JM. Insulin resistence and insulin action. An in vitro and in vivo perspective. Diabetes 1981; 30: 148-62.

11. Saltiel RA. Diverse signaling pathways in the celullar action of insulin. Endocrinol Metab 1996; 33: 375-85.

12. White ME, Kahn CR. The insulin signaling system. J Biol Chem 1994; 269: 1-4.

Received: November 10, 2003

Accepted: February 16, 2004 